\title{
The US\$ 2.1 billion derivative loss that ruined the Brazilian Aracruz
}

\author{
Fernando Dal-Ri Murcia* \\ University of São Paulo, \\ Av. Prof. Luciano Gualberto, 908, FEA 3, \\ 237 - Butantã, São Paulo, SP 05508-010, Brazil \\ Email: murcia@usp.br \\ *Corresponding author
}

\section{Flávia Cruz de Souza Murcia and Elisete Dahmer Pfitscher}

Federal University of Santa Catarina, Centro Socioeconômico - Bloco F, Campus Universitário - Trindade, Florianópolis - Santa Catarina, SC 88040-970, Brazil Email: flavia_csouza@hotmail.com Email: elisete@cse.ufsc.br

\begin{abstract}
This paper critically analyses the case of the Brazil-based Aracruz Celulose S.A., which was one of the world's largest producer of bleached eucalyptus pulp. In 2008, it posted a derivate loss of US\$ 2.1 billion dollars, which is considered the 7th largest derivative loss for all time. For these, we use publicly available information about the case that includes: 1) financial statements; 2) notices of material events announced at the Securities Exchange Commission (SEC) and in the Comissão de Valores Mobiliários (Brazilian Exchange Commission); 3) the administrative proceeding process conducted by Comissão de Valores Mobiliários; 4) the company's website; 5) newspaper and website articles; 6) academic journals. Just before the crisis, Aracruz was a very successful company and its financial structure was solid. That loss caused a huge solvency problem that lead to end of the company. Aracruz went from being a history of success to a situation of financial insolvency. Our analysis evidences that Aracruz was operating as a 'bank', using derivatives to speculate against the US dollar and not really to hedge its revenues, as it was heavily leveraged. The results show the misuse of derivatives can damage a company and even lead to bankruptcy.
\end{abstract}

Keywords: Aracruz; Brazil; derivatives.

Reference to this paper should be made as follows: Murcia, F.D-R., Murcia, F.C.d.S. and Pfitscher, E.D. (2017) 'The US\$ 2.1 billion derivative loss that ruined the Brazilian Aracruz', Int. J. Auditing Technology, Vol. 3, No. 3, pp.217-230.

Biographical notes: Fernando Dal-Ri Murcia is an Associate Professor at University of São Paulo - Brazil. He obtained his PhD in Accounting and Controllership at the University of São Paulo - Brazil. 
Flávia Cruz de Souza Murcia is a Post-Doctoral Researcher at the Federal University of Santa Catarina - Brazil. She obtained her PhD in Finance at the Federal University of Santa Catarina - Brazil

Elisete Dahmer Pfitscher is an Associate Professor at the Federal University of Santa Catarina - Brazil. She obtained her PhD in Production Engineering at the Federal University of Santa Catarina - Brazil.

\section{Introduction}

According Culp (2002), one of the reasons for the enormous success and popularity of derivatives in recent decades is the possibility it offers companies to adjust their risk profiles, facilitating the transfer of certain specific risks. Some reasons for using derivatives are: risk management, speculation, reduction of transaction costs and regulatory arbitrage.

Financial institutions operate derivatives with relative assurance, mediating the negotiation of opposite positions. They generally charge a spread for their services, and sometimes agree to assume the risk through a calculated financial compensation.

For non-financial companies, derivative instruments are intended to protect companies from adverse market variations, enabling the protection or hedging of their commercial or financial operations.

In this case of Brazilian companies, the main risk faced is the exchange rate variation as many of them have debt in US dollars. According to Silva Filho (2013), one of the main factors that increase the vulnerability of Brazil and other emerging countries to contagion from global financial crisis is the heavy reliance on foreign currency debt and capital inflows to finance productive activities.

So, many Brazilian companies implement risk management policies to perform hedging transactions. To implement these hedge transactions, companies use a variety of derivative instruments, like future contracts such as non-deliverable forward (NDF) and long call and put contract options for currencies.

However, according to Perera et al. (2011) derivatives have been used not only as a protection instrument, but also for speculative purposes. According to this author, this becomes a problem because non-financial companies, besides not dominating the expertise to deal with these high-tech instruments of great complexity, also find it more difficult to abandon adverse positions.

This paper critically analyses the case of the Brazil-based Aracruz Celulose S.A., which was one the world's largest producer of bleached eucalyptus pulp, and posted a derivate loss of US\$ 2.1 billion dollars in the year of 2008 .

For these, we use public information available about the case that includes:

1 financial statements

2 notices of material events announced at the Securities Exchange Commission (SEC) and in the Comissão de Valores Mobiliários (Brazilian Exchange Commission)

3 the administrative proceeding process conducted by Comissão de Valores Mobiliários 
4 company's website

5 newspaper and website articles

6 academic journals.

The remainder of this paper is organised as follows. Section 2 presents a brief history of Aracruz and Section 3 describes financial derivatives. In Section 4 we analyse the derivative loss of Aracruz. In Section 5, we present the main consequences of the loss. Section 6 presents our final conclusions.

\section{Brief history of Aracruz}

Brazil-based Aracruz Celulose S.A. was the world's largest producer of bleached hardwood kraft market pulp. They produced eucalyptus pulp, which is a high quality variety of hardwood pulp used by paper manufacturers to produce a wide range of products, including premium tissue, printing and writing papers, liquid packaging board and specialty papers.

Aracruz Florestal S.A., or AFSA, their predecessor, was incorporated in 1967, for an unlimited duration, to plant eucalyptus forests. AFSA became a subsidiary of Aracruz in 1972 when Aracruz was incorporated, and on 20 July 1993, AFSA was merged into Aracruz. Table 1 presents a brief history of Aracruz.

Table 1 Brief history

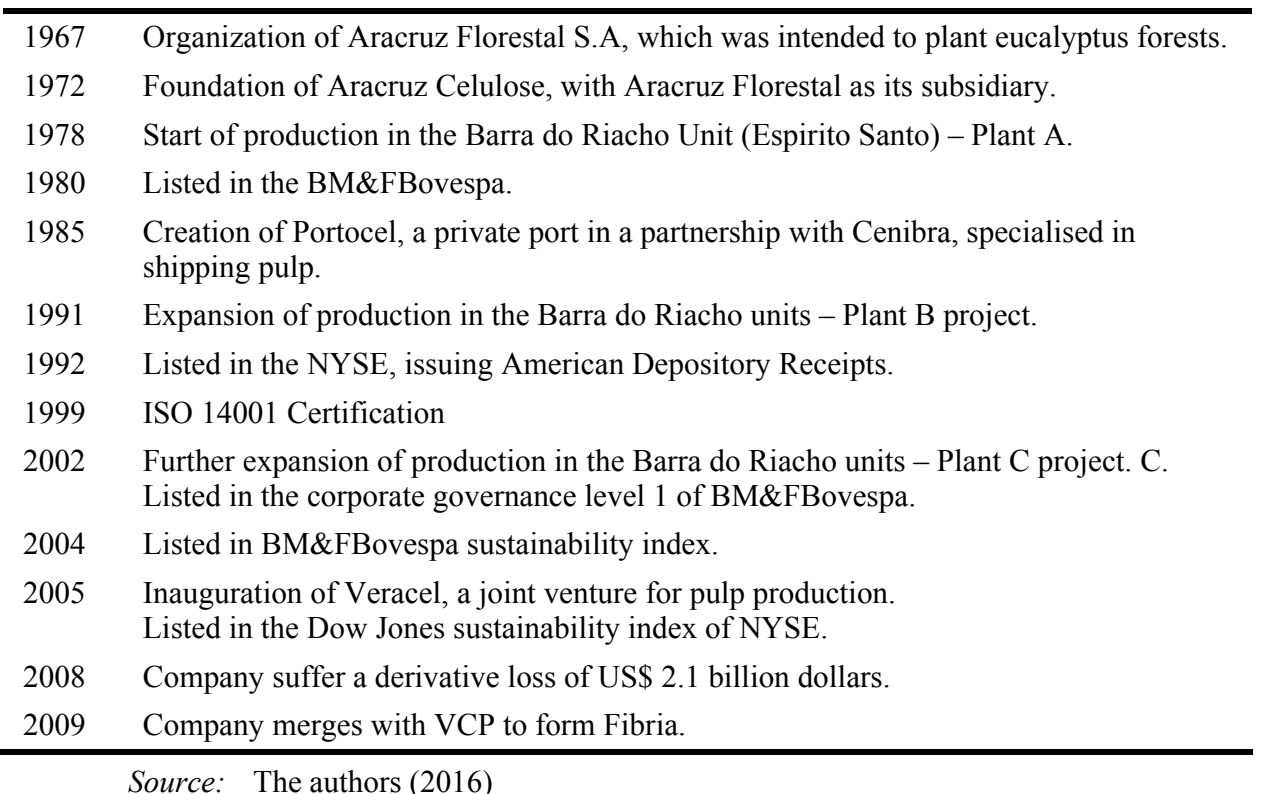

By the year of 2008, before the derivative loss, Aracruz was a very large and successful company:

- Revenues: US\$ 2.1 billion.

- Market cap: US\$ 7.7 billion. 
- Production: 3.1 million tons of cellulose, being the world's largest producer of bleached eucalyptus pulp, as well as one of the lowest-cost producers of this product.

- Exporting: one of the largest Brazilian exporters, as 98\% came from overseas (Asia $23 \%$, North America $34 \%$ and Europe $41 \%$ ).

- Workers: 12,010 direct workers.

- Shares: listed in NYSE since 1992 and BM\&FBovespa since 1980.

- Credit ratings: one of the few companies in Brazil confirmed as investment grade in foreign currency debt from three of the most important rating agencies in the world Moody's, Standard \& Poor's and Fitch Ratings.

- Corporate governance: listed in level 1 of BM\&FBovespa.

- Social and environmental practices: listed in the Dow Jones Sustainability. Index and in the BM\&FBovespa sustainability index.

\section{Derivatives: weapons of mass destruction}

Bernstein (1997) defines derivatives as financial instruments with no intrinsic value, having this name due to the fact that they derive their value from the value of another asset. Gregory (2010) declares that derivative contracts represent agreements, either to make payments or to buy or sell an underlying contract at a future time. Brealey and Myers (2002) affirm that derivatives provide leverage, as it is not necessary to invest a large sum of money at first, and that the profits or losses can be magnified, reaching amounts far above the initial investment.

The four more common types of derivatives, which are: forward contract, futures contract, options and swaps, presents in Table 2.

According to Hull (2008), derivates can be used to:

- hedge risks

- speculate (take a view on the future direction of the market)

- lock in an arbitrage profit

- change the nature of a liability

- change the nature of an investment without incurring the costs of selling one portfolio and buying another.

The participants in a derivative market can be divided into three categories:

- hedgers: use the derivatives markets primarily for price risk management of assets and portfolios

- speculators: take a view whether prices would rise or fall in future and accordingly buy or sell futures and options to try and make a profit from the future price movements of the underlying asset

- arbitrageurs: take short and long positions in the same or different contracts at the same time to create a position which can generate a riskless profit. 
Table 2 Types of derivatives

\begin{tabular}{ll}
\hline Type of derivative & \multicolumn{1}{c}{ Definition } \\
\hline Forward contract & $\begin{array}{l}\text { Bilateral contract negotiated for the physical delivery of an asset or the } \\
\text { cash equivalent at a certain time in the future, for a certain price set at the } \\
\text { beginning of the contract. }\end{array}$ \\
Futures contract & $\begin{array}{l}\text { Standardised forward contract negotiated in an organised market that } \\
\text { gathers buyers and sellers and ensures that both parties fulfil their } \\
\text { obligations. }\end{array}$ \\
Options & $\begin{array}{l}\text { An option grants its holder the right, but not the obligation, to buy or sell } \\
\text { something at a given price, on a specified date or earlier. There are two } \\
\text { basic types of options: call option, which grants its owner, known as the } \\
\text { option holder, the right to buy an asset at a certain price on a given date; on } \\
\text { the other hand, the put option grants the holder the right to sell the asset at } \\
\text { a certain price on a given date. }\end{array}$ \\
Financial strategy where two agents agree to exchange future flows of \\
funds in a predetermined manner. Swaps are traded in private agreements \\
between two parties for the exchange of cash flows or assets at certain \\
times in the future, according to some specified payment formula.
\end{tabular}

Source: The authors (2016)

Most companies, that do not belong in the financial industry (i.e., not banks), act as hedgers as the use derivatives to protect themselves from future risks. Because there are not in the financial sector, they rather focus on the main business and use derivatives to mitigate risks arising from interest rates, exchange rates, and other market variables.

Table 3 The largest derivative losses

\begin{tabular}{|c|c|c|c|c|c|}
\hline Rank & Amount lost & Country & Company & Source & Year \\
\hline 1 & USD 9 bn & USA & Morgan Stanley & $\begin{array}{l}\text { Credit Default } \\
\text { Swaps }\end{array}$ & 2008 \\
\hline 2 & EUR 4.9 bn & France & Société Générale & $\begin{array}{l}\text { European Index } \\
\text { Futures }\end{array}$ & 2008 \\
\hline 3 & USD 6.5 bn & USA & Amaranth Advisors & Gas Futures & 2006 \\
\hline 4 & USD 4.6 bn & USA & $\begin{array}{l}\text { Long Term Capital } \\
\text { Management }\end{array}$ & $\begin{array}{l}\text { Interest Rate and } \\
\text { Equity Derivatives }\end{array}$ & 1998 \\
\hline 5 & USD 5.80 bn & UK & JPMorgan Chase & Credit default swaps & 2012 \\
\hline 6 & JPY 285 bn & Japan & Sumitomo Corporation & Copper Futures & 1996 \\
\hline 7 & BRL 4.62 bn & Brazil & Aracruz & FX Options & 2008 \\
\hline 8 & USD 1.7 bn & USA & Orange County & $\begin{array}{l}\text { Leveraged bond } \\
\text { investments }\end{array}$ & 1994 \\
\hline 9 & DEM 2.63 bn & Germany & Metallgesellschaft & Oil Futures & 1993 \\
\hline 10 & JPY 166 bn & Japan & Showa Shell Sekiyu & FX Forwards & 1993 \\
\hline
\end{tabular}

Source: The authors (2016)

However, some of the largest trading losses in derivatives have occurred because individuals who had a mandate to be hedgers or arbitrageurs switched to being speculators. Luquet (2005) warn that some companies also use these instruments for speculative purposes in order to leverage positions, seeking to maximise the return on 
their investments. Table 3 illustrates the largest derivative losses of time, with Aracruz being ranked seventh.

To Warren Buffet, in his famous message in the Berkshire Hathaway Annual Report of 2002 "derivatives are financial weapons of mass destruction, carrying dangers that, while now latent, are potentially lethal”!

Regarding to scientific research about derivatives, in the international academic field, it can be said that it is at an advanced stage. In this sense, we can highlight the work of Barth et al. (1996), Skinner (1996) Seow and Tam (2002), among others that addressed aspects related to the regulation of derivatives from the viewpoint of FASB, disclosure and predictive value of this information to the capital market.

In the Brazilian academic scenario, it is noted that there are few studies that discuss aspects related to the regulation of derivatives instruments, for example, Carvalho (1999), Lopes (1999), Lopes and Carvalho (1999), and Lopes and Santos (2003). Similarly, other studies, for example, Costa Junior (2003), Darós and Borba (2005), and Moreira et al. (2006) analysed the disclosure of companies with regard to financial instruments, in particular derivatives.

Specifically about the loss of Aracruz, Silva and Pinese (2010) sought to demonstrate how the target forward operations were structured.

Lemos and Sá (2013) analysed the economic-financial and administrative impact on Sadia, Aracruz Celulose and Votorantim (industrial segment) due to the use of derivatives in speculatively. Therefore, it was calculated financial ratios and analysed the annual financial reports for the period 2006 to 2008.

\section{The exotic derivative loss of Aracruz}

As mentioned before, 98\% of Aracruz revenues came from abroad. In this sense, it had almost of its receivables in foreign currency, mainly US dollars. In the early 2000 s, despite the cellulose price increase at the time due to the strong demand, the devaluation of the Brazilian currency, the Real, came to be unfavourable to Aracruz.

In 2003, Brazil started a new cycle of Real appreciation relative to the US dollar and the rate in that year was $18.2 \%$. In 2004 the appreciation of the Real relative to the US dollar was $8.1 \%$, in 2005 the Real appreciated $11.8 \%$ and in 2006 the Real appreciated approximately $9.0 \%$. In 2007 the appreciation of the Real relative to the US dollar was $17.2 \%$, representing an accumulated appreciation of $49.7 \%$ since the beginning of 2003 . Overall, the Brazilian Real advanced from R $\$ 3.95$ to the dollar in October 2002 to $\mathrm{R} \$$ 1.56 in July of 2008.

So, to protect itself from fluctuations in the Real prices, it made sense to use derivative financial instruments. Aracruz, as a big exporting company, would use financial derivatives to protect its revenue in US dollars against exchange rate variations.

Thus, Aracruz began in 2004 to use financial derivatives in 2004. Since it had receivables in US dollars, it began selling forward contracts of US dollars by using derivatives. The company engaged in an operation called target forward, where it basically sold a forward contract with a fixed dollar rate to the counterpart, a financial institution. Basically, a short position in US dollars.

Overall, this transaction would not represent a big risk to the company; as long as the contract had the same amount and timing as the revenues it expected to receive from exports. As companies like to say, this is 'natural hedge'. 
The target price in the derivatives contracts was higher than the spot price. In this sense, the company was able to maximise its derivatives revenues during the appreciation of the Brazilian Real against the US dollar. Due to this strategy, the company obtained cumulative gains of R\$ 630 million until the third quarter of 2008.

The problem, which was latter to be found, was that there was also a cap in the target forward contracts, whenever the US dollar rose above a certain specified price. In this case, the company would have to sell twice the amount of the contract.

Financial managers did not expect that the US dollar would raise so much in the short term to exceed the target price. Also, they figured that the options would bring much larger profits than the conventional forwards. The company bet on the continued rise of the Brazilian Real against the US dollar, which appreciated until August 2008 on the belief that Brazil would be largely immune from the credit crisis.

In 2005 and during 2006, the risk rating agencies Moody's investor service (Moody's), Standard \& Poor's and Fitch Ratings (Fitch) both assigned an indicative rating to the Company's foreign currency debt under foreign law. After the rating agencies' confirmation, Aracruz became one of the few companies in Brazil confirmed as investment grade in foreign currency debt from three of the most important rating agencies.

Everything seemed fine, as long as the Brazilian Real kept appreciating against the US dollars. The company was making money and it had an investment grade rating.

However, Aracruz was not hedging with derivatives; it was speculating in the financial market. There were lots of hidden risks, as with options, when you are short, the risk is unlimited, as they would latter find out.

So, whenever the dollar rose, the company had to buy US dollar in the financial market and sell to the bank for the specified price. In the case, lower than the market price, which generated an immediately loss.

Figure 1 illustrates the rise of the US dollar against the Brazilian Real during the financial crisis.

Figure 1 US dollar/BR real exchange rate: September to November (2008)

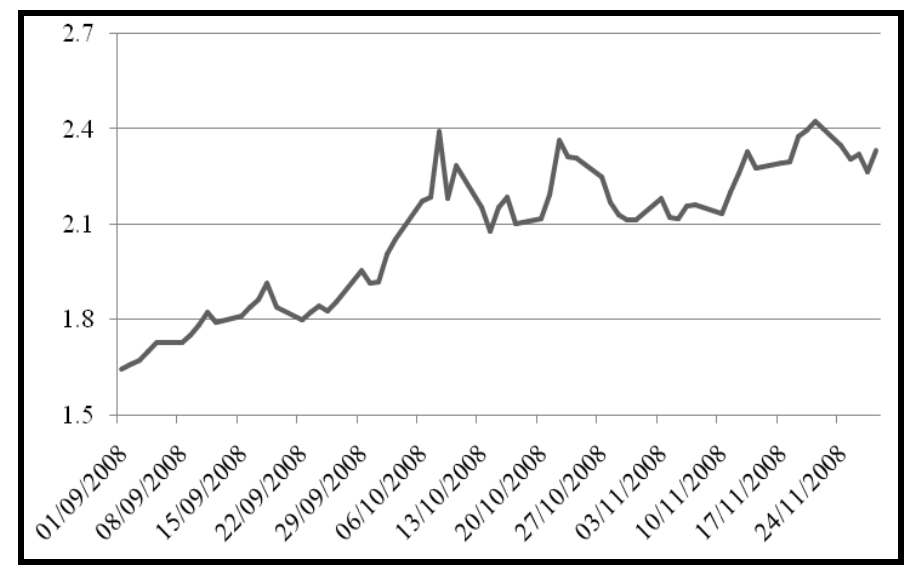

Source: The authors (2016) 
The Aracruz situation became public in 25th of September of 2008, when the company announced notices of material events in the SEC, in the CVM and in the main Brazilian newspapers. Table 4 illustrates these notices.

Table 4 Notices of material events announced by Aracruz regarding the derivative loss

\begin{tabular}{|c|c|}
\hline Date & Material events \\
\hline $\begin{array}{l}25 \text { September } \\
2008\end{array}$ & $\begin{array}{l}\text { "[...] On this date the members of the company's board of directors were } \\
\text { informed by the Company's internal controls and compliance committees that the } \\
\text { Company's current exposure to the financial derivatives instruments (called } \\
\text { 'target forward') has been strongly affected by the recent US dollar trade prices } \\
\text { instability, caused by the high volatility moment experienced by the markets } \\
\text { throughout the world. The Company's Board of Directors were also told that: (1) } \\
\text { the maximum loss volume on derivative transactions and also the total exposure } \\
\text { to futures contracts based on US dollars may have exceeded the limits set forth in } \\
\text { Company's Financial Policy approved by the Board of Directors; (2) the } \\
\text { Company's management has been taking all measures necessary to gradually } \\
\text { reduce the Company's exposure to such derivatives transactions so as to } \\
\text { minimize the impact in the Company's business; (3) to enhance the Company's } \\
\text { related internal control; and (4) in order to provide information to the Chief } \\
\text { Executive Officer and also to the members of the Company's Board of Directors, } \\
\text { it was necessary to verify and determine the current market value of the } \\
\text { Company's open interests and total exposures for which purpose the Company } \\
\text { has hired a specialized firm. [...] As soon as the analysis of the current market } \\
\text { value of the Company's position in the contracts to which it is still a party is } \\
\text { completed, the results will be promptly disclosed to the market based on the } \\
\text { financial information at September 30, 2008." }\end{array}$ \\
\hline $\begin{array}{l}2 \text { October } \\
2008\end{array}$ & $\begin{array}{l}\text { "[...] A consulting firm hired to analyze the Company's operations with } \\
\text { derivative instruments examined derivative contracts maintained by the } \\
\text { Company and determined a 'fair value' of such contracts of approximately } \\
\text { negative US } \$ 1.02 \text { billion, utilizing the base date of September } 30,2008 . "\end{array}$ \\
\hline $\begin{array}{l}3 \text { November } \\
2008\end{array}$ & $\begin{array}{l}\text { "[...] On this date, the Company has reached an agreement with several banks, } \\
\text { counterparties in various derivative transactions entered into with the Company. } \\
{[\ldots] \text { In order to facilitate such restructuring, in addition on this date, the }} \\
\text { derivative transactions that had been entered into with the Banks were } \\
\text { terminated, thereby eliminating } 97 \% \text { of the Company's derivative exposure. As a } \\
\text { result, the Company has recorded a related total loss of approximately US\$2.13 } \\
\text { billion." }\end{array}$ \\
\hline
\end{tabular}

Source: The authors (2016)

As illustrated by Table 4, in the first moment, not even the Board of Directors of Aracruz really knew how bad the situation was. It was only in November that the company was able to recognise the size of the loss: US\$ 2.13 billion dollars. Table 5 evidences the total loss disclosed by Aracruz in its 20-F Form of 2008.

Also, by analysing Aracruz results from 2006-2008, in a quarterly-based, it is possible to see that the derivative operations became very relevant as a percentage of net profit. Table 6 illustrates these analyses. 
Table 5 Aracruz 20-F Form (see online version for colours)

- Gains and losses in the period, grouped by main categories of risk assumed, those recorded in income (loss) and those recorded in shareholders' equity are segregated.

\begin{tabular}{lcc}
\hline \multicolumn{2}{l}{ Breakdown of consolidated gains (losses) on derivative transactions: } \\
\cline { 2 - 3 } & \multicolumn{2}{c}{ As of December $\mathbf{3 1}$} \\
\cline { 2 - 3 } & $\mathbf{2 0 0 7}$ & $\mathbf{2 0 0 8}$ \\
\hline Future DI - BM\&F & $(36,354)$ & 2,196 \\
Future US\$ - BM\&F & 93,670 & 98,408 \\
Non deliverable forward (NDF) & & $(19,608)$ \\
Interest rate swap & 38,321 & $(63,377)$ \\
Sell target forward ${ }^{(i)}$ & & $(1,830,763)$ \\
Swap libor (prepayment) ${ }^{(\mathrm{i})}$ & & $(351,083)$ \\
Sell target forward (NDF) & 4,972 \\
Total & 95,637 & $(2,159,255)$ \\
\hline
\end{tabular}

Notes: ${ }^{(i)}$ The 2008 losses on sell target forward and swap libor (prepayment) resulted from the company's short position in US dollars at the time when exchange rates trends changed abruptly and sharply, requiring the company to close its positions in order to curtail its losses.

Source: The authors (2016)

Table 6 Aracruz results: 2006-2008

\begin{tabular}{cccccc}
\hline Period & & Gross revenue & Derivatives & Net profit & $\begin{array}{c}\text { Derivatives } \text { net } \\
\text { profit }\end{array}$ \\
\hline 2006 & $1^{\circ}$ trimester & 1.022 .245 & 140.000 & 348.980 & 0.401 \\
& $2^{\text {o }}$ trimester & 1.039 .664 & 6.000 & 227.949 & 0.026 \\
& $3^{\circ}$ trimester & 1.122 .664 & 19.000 & 277.467 & 0.068 \\
& $4^{\circ}$ trimester & 1.200 .469 & -76.000 & 295.735 & -0.256 \\
& Annual & 4.385 .042 & 89.000 & 1.150 .131 & 0.077 \\
& $1^{\circ}$ trimester & 1.016 .497 & 69.957 & 273.243 & 0.256 \\
& $2^{\circ}$ trimester & 1.166 .184 & 80.510 & 321.490 & 0.250 \\
& $3^{\circ}$ trimester & 1.043 .950 & 41.551 & 263.248 & 0.157 \\
& $4^{\circ}$ trimester & 1.125 .544 & 7.368 & 184.223 & 0.040 \\
& Annual & 4.352 .175 & 199.386 & 1.042 .204 & 0.19131 \\
& $1^{\circ}$ trimester & 1.009 .754 & 23.011 & 166.507 & 0.138 \\
& $2^{\circ}$ trimester & 1.044 .326 & 110.645 & 263.655 & 0.419 \\
& $3^{\circ}$ trimester & 941.746 & -2.100 .036 & -1.657 .663 & 1.266 \\
& $4^{\circ}$ trimester & 1.138 .804 & -2.729 .188 & -2.985 .954 & 0.914 \\
& Annual & 4.134 .630 & -4.695 .568 & -4.213 .455 & 1.114 \\
\hline
\end{tabular}

Source: The authors (2016) 
By the size of the loss, we can see that Aracruz massively increased the size of its derivatives positions. Zeidan and Rodrigues (2013) estimated the derivatives positions were nearly six times the company's exposure. So the company was essentially speculating hugely on the USD falling against the BRL. The instruments it used were correspondingly aggressive, as the target forwards in which the loss the company would face if the dollar appreciated were twice the benefit would reap if the dollar depreciated by a like amount.

It is worthwhile mentioning that, at that time - 2008 -, the disclosure of derivative operations by most of Brazilian companies was quite reduced (Murcia and Santos, 2009). This is because, by that time, Brazilian GAAP did not have a specific standard for financial instruments. In fact, in 2008, derivative operations were treated as off-the-balance-sheet items.

Due to this lack of accounting and disclosure standard, financial statements only evidenced the realised results, as unrealised results and fair value of positions were only disclosure in footnotes. So overall, it was quite difficult for users to understand the magnitude and the risks of Aracruz derivative transactions. However, the fact that the company had constantly used derivatives and made financial profits out of it was for sure a red flag.

Due to the Aracruz scandal, as well as others like Sadia and Vicunha in 17 December of 2008, the Brazilian Exchange Commission, approved two new Accounting Standards regarding recognition, measurement and disclosure of financial instruments: CVM $\mathrm{N}^{\circ}$ 566 (CVM, 2008b) and CVM N 475 (CVM, 2008a). Because Brazil has agreed to fully adopt International Financial Reporting Standards (IFRS) by 2010, these new Brazilian standards are already based on the IAS 39 - financial instruments recognition and measurement, on the IAS 32 - financial instruments: disclosure and presentation and IFRS 7 - financial instruments: disclosure.

So, these new standards wished to change dramatically the way companies recognised and measured their financial instruments. Also, as these standards became applicable immediately, i.e., 17 December of 2008, Brazilian companies had to adapt their financial statements for the year ended in 2008, which are published in 2009.

In the Aracruz case, disclosure was also a problem. According to Perera et al. (2011), the stakeholders were never informed that the company was using derivative financial instruments to leverage results.

\section{The main consequences of the derivative loss}

Two months after the announcement of the derivative loss, Aracruz's preferred shares had already lost $85 \%$ of value.

Due to the loss, Its debt rose up to R $\$ 8.7$ billion which lead the company to break down most of its debt covenants. Its Debt to Equity Ratio was almost nine. It seemed that the company was not going to be able to renegotiate is debt. Because of that Delloitte Touche Tohmatsu, their auditor mention, in their auditor's opinion, the possibly of discontinuity.

That was the end of Aracruz, as we knew it. Notices of material events announced in the SEC, in the CVM and in the main Brazilian newspapers already indicated that (Table 7). 
Table 7 Notices of material events announced by Aracruz regarding the merger with VCP

\begin{tabular}{|c|c|}
\hline Date & Material events \\
\hline $\begin{array}{l}20 \text { January } \\
2009\end{array}$ & $\begin{array}{l}\text { "[...] Aracruz Celulose S.A. announces that, on this date, the company received the } \\
\text { following Material Information Release that will be reproduced as follows: } \\
\text { Management of Votorantim Celulose e Papel S.A. (VCP) hereby announces }[\ldots] \\
\text { the following: VCP has concluded negotiations with members of the Lorentzen, } \\
\text { Moreira Salles and Almeida Braga families (the Families) for VCP to acquire } \\
127,506,457 \text { common shares issued by Aracruz Celulose S.A., representing } \\
\text { approximately } 28.03 \% \text { of the voting capital of Aracruz. The transaction is expected } \\
\text { to close on January } 21,2009 \text {. The purchase price of R } \$ 2,710,000,000 \text { is to be paid } \\
\text { in six tranches." }\end{array}$ \\
\hline $\begin{array}{l}31 \text { March } \\
2009\end{array}$ & $\begin{array}{l}\text { "[...] Aracruz Celulose S.A. announces that Votorantim Celulose e Papel S.A. } \\
\text { (VCP) has timely filed with the Brazilian securities commission a request to } \\
\text { register a mandatory change of control tender offer that seeks to buy any and all of } \\
\text { the outstanding Aracruz common shares. As required under the BCL, VCP will } \\
\text { offer holders of Aracruz common shares R } \$ 17.0031 \text { per Aracruz common share, } \\
\text { which corresponds to } 80 \% \text { of the purchase price that VCP paid to purchase the } \\
\text { Aracruz common shares owned by the Lorentzen, Moreira Salles, Almeida Braga } \\
\text { and Safra families. Pursuant to the BCL, such mandatory change of control tender } \\
\text { offer to purchase outstanding common shares of a company is required to be } \\
\text { launched by an acquirer of a company's corporate control." }\end{array}$ \\
\hline $\begin{array}{l}30 \text { April } \\
2009\end{array}$ & $\begin{array}{l}\text { "[...] Aracruz Celulose S.A. announces that it has received a communication from } \\
\text { the Safra family, dated April 29, 2009, saying that, on that date, they consummated } \\
\text { the sale of } 127,506,457 \text { common nominative shares issued by Aracruz, transferring } \\
122,801,422 \text { of those shares to São Teófilo Representações e Participações S.A., an } \\
\text { affiliate of Votorantim Celulose e Papel S.A. (VCP), and 4,705,035 to VCP. The } \\
\text { settlement of this transaction with the Safra family reaffirms the 'tag along' rights } \\
\text { provided for in the shareholders' agreement between the Safra, Lorentzen, Moreira } \\
\text { Salles and Almeida Braga families, and represents the consolidation of the earlier } \\
\text { deal carried out with the Lorentzen, Moreira Salles and Almeida Braga families, } \\
\text { awarding VCP, on April } 29,2009 \text {, the direct and indirect ownership of } \\
\text { approximately } 84 \% \text { of Aracruz's voting capital." }\end{array}$ \\
\hline $\begin{array}{l}1 \text { June } \\
2009\end{array}$ & $\begin{array}{l}\text { "[...] Votorantim Celulose e Papel S.A and Aracruz Celulose S.A.announce that the } \\
\text { Boards of Directors of both companies have held meetings on June 1, } 2009 \text { and } \\
\text { after (1) having been made aware of the discussions between the VCP's Special } \\
\text { Independent Committee and the Aracruz Special Independent Committee; (2) } \\
\text { having examined the reports provided by the Committees; and (3) having discussed } \\
\text { the conclusions of the Committees, unanimously decided to set the exchange ratio } \\
\text { of } 0.1347 \text { VCP common share for one Aracruz common share in the context of an } \\
\text { Aracruz and VCP stock swap merger." }\end{array}$ \\
\hline $\begin{array}{l}26 \text { August } \\
2009\end{array}$ & $\begin{array}{l}\text { "[...] Managements of Votorantim Celulose e Papel S.A. (VCP) and Aracruz } \\
\text { Celulose S.A. hereby inform the market that their respective Extraordinary General } \\
\text { Shareholders' Meetings (the EGMs) were reinitiated and concluded on this date. } \\
\text { Both EGMs approved the merger of the Aracruz shares, not held directly or } \\
\text { indirectly by VCP, into VCP's asset-base." }\end{array}$ \\
\hline
\end{tabular}

Source: The authors (2016)

It is important to mention that, the Brazilian Exchange Commission, CVM, analysed the case in 2010. The accusations were as follows:

- The company did not disclose, in the Footnotes of the Intermediary Reports ended in June of 2008, the market value of derivatives, as well as the criteria for valuing these financial instruments; responsible: $\mathrm{CEO}$ and $\mathrm{CFO}$. 
- Financial Committee and Auditing Committee were not diligent in verifying these transactions; responsible: members of the Financial and Auditing Committee.

- Board of Directors was not diligent in obtaining more information regarding financial derivative transactions whenever they were informed by the Financial Area; responsible: two members of the Board of Directors.

All the people found responsible were fined by the CVM. The CFO of the Aracruz paid R\$ 1,5 million to settle the case. The others, CEO and the members of the Financial and Auditing Committee paid R\$ 1.0 million each (CVM, 2010).

It is worthwhile mentioning that Deloitte Touche Tohmatsu, and the auditing partner responsible for Aracruz, were also considered guilty in the process. The paid R\$ 1.0 million to settle the case.

\section{Final considerations}

This paper critically reviews the case of Aracruz, which was one of the largest cellulose companies in the world. In the year of 2008, it posted a derivate loss of US\$ 2.1 billion dollars, which is considered the seventh largest derivative loss in all times, ahead of famous losses like Orange Country and UBS.

Just before the crisis, Aracruz was a very successful company, with very impressive numbers:

1 revenues of US\$ 2.1 billion

2 market cap of US\$ 7.7 billion

3 production of 3.1 million tons of cellulose, being the world's largest producer of bleached eucalyptus pulp, as well as one of the lowest-cost producers of this product.

Its financial structure was solid. It was one of the few companies in Brazil confirmed as investment grade in foreign currency debt from three of the most important rating agencies in the world Moody's, Standard \& Poor's and Fitch Ratings. His corporate governance was admirable being listed in both Dow Jones Sustainability Index and in the BM\&FBovespa sustainability index.

However, the effect of derivative loss was too big for the company to handle. Aracruz went from being a history of success to a situation of financial insolvency. The company was eventually acquired by its smaller competitor VCP, and the new merged company was renamed Fibria.

According to the literature reviewed in this paper, the following causes contributed to the Aracruz derivative loss:

- The company became a 'bank', using derivative as speculation. It took huge positions on NDFs, that had a call option embedded, betting against the rise of US dollar.

- Formal Corporate Governance mechanisms were not effective. The company was listed in BM\&FBovespa Corporate Governance Levels and was subject to SEC scrutiny and SOX as it was listed in the NYSE. Management, board of directors and auditing committee were found guilty by CVM for negligence. 
- Aracruz did not fully recognised in its financial statements, as under BR GAAP, derivatives financial instruments were treated as off-balance sheet items. Also, company was founded guilty by CVM for not properly disclosing these operations in the Footnotes.

In conclusion, our paper evidences that Aracruz was operating as a financial institution, using derivatives to speculate against the US dollar and not really to hedge its revenues, as it was heavily leveraged. We have showed that the misuse of derivatives can damage a company and even lead to bankruptcy.

\section{References}

Barth, M., Beaver, W. and Landsman, W. (1996) 'Value-relevance of banks' fair value disclosures under SFAS no. 107', The Accounting Review, Vol. 71, No. 4, pp.513-537.

Bernstein, P. (1997) Desafio aos deuses: a fascinante história do risco, Campus, São Paulo.

Brealey, R. and Myers, S. (2002) Financing and Risk Management, McGraw-Hill, USA.

Carvalho, N. (1999) 'Evidenciação de derivativos', Caderno de Estudos, Vol. 20, No. 1, pp.1-16.

Comissão de Valores Mobiliários (CVM) (2008a) Instrução CVM No 475, de 17 de dezembro de 2008 [online] http://www.cvm.gov.br/export/sites/cvm/legislacao/inst/anexos/400/inst475.pdf (accessed 16 January 2016).

Comissão de Valores Mobiliários (CVM) (2008b) Deliberação CVM No 566, de 17 de dezembro de 2008 [online] http://www.cvm.gov.br/export/sites/cvm/legislacao/inst/anexos/ 500/inst566.pdf (accessed 16 January 2016).

Comissão de Valores Mobiliários (CVM) (2010) Decisão do colegiado de 30/11/2010 [online] http://www.cvm.gov.br/decisoes/2010/20101130_R1/20101130_D07.html (accessed 21 May 2015).

Costa Junior, J. (2003) 'Uma avaliação do nível de evidenciação das companhias abertas, no Brasil, no tocante aos instrumentos financeiros', Revista Contabilidade e Finanças, Vol. 14, No. 32, pp.23-39.

Culp, C.L. (2002) The Art of Risk Management, John Wiley, New York.

Darós, L. and Borba, J.A. (2005) 'Evidenciação de instrumentos financeiros derivativos nas demonstrações contábeis: Uma análise das empresas brasileiras', Revista Contabilidade e Finanças, Vol. 16, No. 39, pp.68-80.

Gregory, J. (2010) Counterparty Credit Risk: The New Challenge for Global Financial Markets, John Wiley, Chichester.

Hull, J.C. (2008) Options, Futures, and other Derivatives, 7th ed., Prentice Hall, USA.

Lemos Junior, F.J. and Sá, F.F. (2013) 'Análise dos impactos econômico-financeiros e administrativos na utilização de derivativos especulativos pelas empresas Sadia, Aracruz Celulose e Votorantim', Revista de Auditoria, Governança e Contabilidade, Vol. 1, No. 2, pp.37-57.

Lopes, A. (1999) 'Uma análise crítica do arcabouço teórico do SFAS 133: acounting for derivative and hedging activities', Caderno de Estudos, Vol. 22, No. 3, pp.1-15.

Lopes, A. and Carvalho, N. (1999) 'Contabilização de operações com derivativos: Uma comparação entre o SFAS N 133 e o arcabouço emanado pelo COSIF', Caderno de Estudos, Vol. 20, No. 1, pp.1-23.

Lopes, A. and Santos, N. (2003) 'A administração do lucro contábil e os critérios para determinação da eficácia do hedge accounting: Utilização da correlação simples dentro do arcabouço do SFAS no 133', Revista Contabilidade e Finanças, Vol. 14, No. 31, pp.16-25.

Luquet, M. (2005) Guia valor econômico de investimentos em ações, Editoras Globo, São Paulo. 
Moreira, C., Niyama, J. and Santana, C. (2006) 'Avaliação do nível de evidenciação contábil de operações com derivativos: Uma comparação entre as informações enviadas à CVM e à SEC pelas companhias abertas brasileiras emissoras de ADR', in Congresso USP de Controladoria e Contabilidade, Vol. 6, São Paulo.

Murcia, F.D.R. and Santos, A. (2009) 'Regulação contábil e a divulgação de informações de operações com instrumentos financeiros derivativos: análise do impacto da CVM No.566/08 e da CVM No. 475/08 no disclosure das companhias abertas no Brasil', Revista de Contabilidade e Organizações, Vol. 3, No. 6, pp.3-21.

Perera, L., Reis Neto, C., Alves, R. and Kerr, R. (2011) Derivatives and Financial Crisis: The Costs of Speculation in Brazil (Aracruz and Sadia), Social Science Research Network - SSRN [online] http://papers.ssrn.com/sol3/papers.cfm?abstract_id=2142870 (accessed 5 November 2015).

Seow, G. and Tam, K. (2002) 'The usefulness of derivative-related accounting disclosures', Review of Quantitative Finance and Accounting, Vol. 18, No. 3, pp.273-291.

Silva Filho, E.B. (2013) 'Financiamento e exposição cambial das firmas brasileiras após a crise de 2008: condicionantes e impactos sistêmicos', in Cintra, M.A.M. and Silva Filho, E.B.d. (Orgs.): Financiamento das corporações: perspectivas do desenvolvimento brasileiro, Ipea, Brasília.

Silva, B. and Pinese, H. (2010) 'A crise financeira internacional e o efeito dos derivativos cambiais: a operação de target forward da Aracruz Celulose', Revista de Administração, Contabilidade e Economia da FUNDACE, Vol. 1, No. 2, pp.1-14.

Skinner, D. (1996) 'Are disclosures about bank derivatives and employee stock options 'value-relevant?', Journal of Accounting and Economics, Vol. 22, Nos. 1-3, pp.393-405.

Zeidan, R. and Rodrigues, B. (2013) 'The failure of risk management for nonfinancial companies in the context of the financial crisis: lessons from Aracruz Celulose and hedging with derivatives', Applied Financial Economics, Vol. 23, No. 3, pp.241-250. 